\title{
Analysis of the adult thymus in reconstitution of T lymphocytes in HIV-1 infection
}

\author{
Barton F. Haynes, ${ }^{1}$ Laura P. Hale, ${ }^{1}$ Kent J. Weinhold, ${ }^{1}$ Dhavalkumar D. Patel, ${ }^{1}$ \\ Hua-Xin Liao, ${ }^{1}$ Peter B. Bressler, ${ }^{1}$ Dawn M. Jones, ${ }^{1}$ James F. Demarest, ${ }^{1}$ \\ Kristin Gebhard-Mitchell, ${ }^{2}$ Ashley T. Haase, ${ }^{2}$ and John A. Bartlett ${ }^{1}$ \\ ${ }^{1}$ Departments of Medicine, Surgery, and Pediatrics, and the Duke Center for AIDS Research, Duke University Medical Center, \\ Durham, North Carolina 27710, USA \\ ${ }^{2}$ Department of Microbiology, the University of Minnesota, Minneapolis, Minnesota 55455, USA \\ Address correspondence and reprint requests to: Barton F. Haynes, Box 3703, Duke Hospital, Durham, North Carolina 27710, USA.
} Phone: (919) 684-5384; Fax: (919) 681-8992; E-mail: Hayne002@mc.duke.edu

Received for publication September 14, 1998, and accepted in revised form December 22, 1998.

\begin{abstract}
A key question in understanding the status of the immune system in HIV-1 infection is whether the adult thymus contributes to reconstitution of peripheral $T$ lymphocytes. We analyzed the thymus in adult patients who died of HIV-1 infection. In addition, we studied the clinical course of HIV-1 infection in three patients thymectomized for myasthenia gravis and determined the effect of antiretroviral therapy on $\mathrm{CD}^{+} \mathrm{T}$ cells. We found that five of seven patients had thymus tissue at autopsy and that all thymuses identified had inflammatory infiltrates surrounding lymphodepleted thymic epithelium. Two of seven patients also had areas of thymopoiesis; one of these patients had peripheral blood CD4 ${ }^{+} \mathrm{T}$-cell levels of $<50 / \mathrm{mm}^{3}$ for 51 months prior to death. Of three thymectomized patients, one rapidly progressed to AIDS, one progressed to AIDS over seven years (normal progressor), whereas the third remains asymptomatic at least seven years after seroconversion. Both latter patients had rises in peripheral blood $\mathrm{CD} 4^{+} \mathrm{T}$ cells after antiretroviral therapy. Most patients who died of complications of HIV-1 infection did not have functional thymus tissue, and when present, thymopoiesis did not prevent prolonged lymphopenia. Thymectomy before HIV-1 infection did not preclude either peripheral CD4 ${ }^{+} \mathrm{T}$-cell rises or clinical responses after antiretroviral therapy.
\end{abstract}

J. Clin. Invest. 103:453-460 (1999)

\section{Introduction}

The human peripheral T-cell pool begins to be established early in fetal development after passage of developing thymocytes through the thymic microenvironment and emigration of mature thymocytes into peripheral sites such as lymph nodes and spleen (1). Although the thymus is essential for establishing the peripheral T-cell pool in early life and maintains thymopoiesis to varying degrees throughout life, recent data have demonstrated an age-dependent decline in thymus function in normal subjects (2-4). Whereas children rapidly reconstitute their peripheral $\mathrm{CD}^{+}{ }^{+} \mathrm{T}$-cell population after cytotoxic chemotherapy, repopulation of the T-cell pool after chemotherapy in adults older than 20 years of age is prolonged and is primarily due to proliferation of peripheral $T$ cells in a thymic-independent manner $(3,4)$.

HIV-1 infection results in progressive loss of peripheral CD4 ${ }^{+} \mathrm{T}$ cells and leads to severe immune deficiency and opportunistic infections. The mechanisms of CD $4^{+}$ T-cell loss in HIV-1 infection have been attributed to viral-induced $\mathrm{CD}^{+} \mathrm{T}$-cell death $(5,6)$ and to progressive destruction of immune-cell microenvironments $(7,8)$.

Highly active combination antiretroviral therapy (HAART) usually leads to rises in $\mathrm{CD}^{+}, \mathrm{CD}^{+} 5 \mathrm{RO}^{+}$ (memory-phenotype) T cells, as well as to late rises in $\mathrm{CD}^{+}, \mathrm{CD}^{4} \mathrm{RA}^{+}$(naive-phenotype) $\mathrm{T}$ cells $(9,10)$. Although rises in peripheral T-cell numbers with HAART can be associated with improvement in survival
(11), HAART-associated CD4 ${ }^{+}$T-cell levels do not usually reach normal levels $(9,10)$. A critical question regarding HIV pathogenesis is whether the thymus contributes to the immune reconstitution of peripheral $\mathrm{T}$ cells in AIDS, especially after the initiation of HAART. Moreover, for design of immune reconstitution strategies in AIDS, it is critical to understand the functional status of the thymus in HIV-1-infected persons and to devise ways to maximize thymopoietic function.

We studied these questions in two ways. First, we evaluated mediastinal tissue from seven adult patients who died of complications of HIV-1 infection for the presence of thymus, for inflammation, and for areas of active thymopoiesis. Second, we studied three thymectomized patients with HIV-1 infection to determine directly the effect of loss of the thymus on the clinical course of HIV-1 infection and on the ability to respond to HAART with rises in $\mathrm{CD}^{+}{ }^{+} \mathrm{T}$ cells.

\section{Methods}

Tissue acquisition and processing. Mediastinal tissue was obtained on a Duke Institutional Review Board-approved protocol from seven patients studied at the time of death due to HIV-1-related complications. Tissue was processed for paraffin embedding for immunohistological analysis with antikeratin monoclonal antibodies (MABs) AE1 and AE3 (DAKO Corp., Carpinteria, California, USA) and CAM5.2 (identifies thymic epithelium; Becton Dickinson, Oxnard, California, USA). Other antibodies 


\section{Figure 1}

Immunohistological analysis of the thymus in HIV infection. (a-d) Thymus from HIV-1+ patient no. 1 with no thymopoiesis. $(\boldsymbol{e}-\boldsymbol{h})$ Thymus from $\mathrm{HIV}-1^{+}$patient no. 2 with areas of active thymopoiesis. (a) Hematoxylin and eosin stain of patient no. 1's lymphoid thymus. $\times 13$. (b) A similar area as in $a$, with thymic epithelium in immunohistological analysis reactive with antikeratin antibody (brown central areas). All keratin ${ }^{+}$thymic epithelium $(e)$ in the true thymus is collapsed (dark brown areas) and devoid of lymphocytes, with a surrounding infiltrate of blue mononuclear cells present in the thymic perivascular space $(P) . \times 13$. (c) Immunohistological stain of CD8 ${ }^{+} T$ cells (brown cells; see arrows for examples) in the perivascular space $(P)$ around a central empty thymic epithelial island $(e)$. The dotted line surrounds thymic true epithelial thymus areas $(e)$, and the short arrow points out a rare $\mathrm{CD}^{+} \mathrm{T}$ cell within the true epithelial thymus (e). $\times 66$. (d) Many of the perivascular space $(P) \mathrm{CD}^{+}$cells are reactive with MAB TIA-1 (arrows) and therefore are mature effector cytotoxic T cells. $\times 66$. $e-h$ are from patient no. 2's thymus. $\times 33$. (e) Light microscopic view of patient no. 2's thymus (hematoxylin and eosin stain with a Hassall's body $[h]$ in the thymus medulla). ( $f$ ) Immunohistological analysis with antikeratin antibody, with areas of normal-appearing keratin ${ }^{+}$thymic epithelium (brown areas) filled with lymphocytes (blue areas) intermingled with thymic epithelium (arrows). Most developing thymocytes are $\mathrm{CD}^{+} \mathrm{T}$ cells (arrows in $\mathrm{g}$ ), many of which are normal CD1 $\mathrm{a}^{+}$cortical thymocytes (brown cells, arrows in $h$ ). A subset of these $\mathrm{CD}_{1} \mathrm{a}^{+}, \mathrm{CD}^{+}$immature thymocytes were actively dividing as determined by nuclear reactivity with MAB mib-1 (not shown). $M A B$, monoclonal antibody.
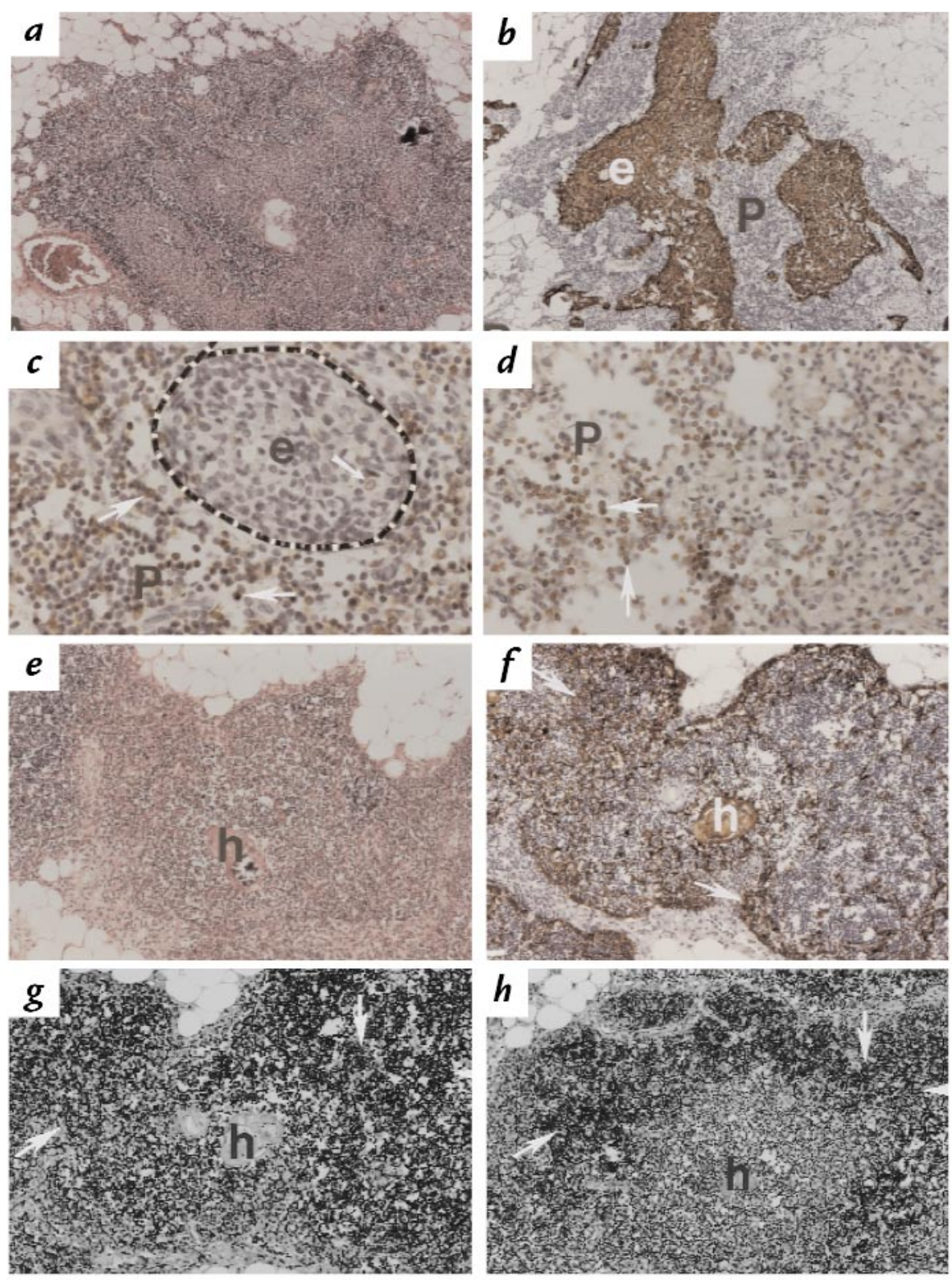

used were as follows: polyclonal rabbit anti-CD3 (anti-T cell; DAKO Corp.); anti-CD1a MAB 010 (anti-immature cortical thymocyte; gift of L. Boumsell, Institute Gustave-Roussy, Paris, France); anti-CD8 MAB (anticytotoxic T cell or their precursors; DAKO Corp.); anti-Ki-67 MAB mib-l (identifies proliferating cells) (12); and MAB TIA-1 (identifies mature cytotoxic effector $T$ cells; gift of P. Anderson, Harvard University, Boston, Massachusetts, USA) (13).

Identification and study of HIV-1-infected thymectomized patients. Three patients (nos. 8, 9, and 10) were identified who had histories of thymectomy for myasthenia gravis and who later developed HIV-1 infection. All were studied using Duke Institutional Review Board-approved informed consent protocols.

Phenotypic analysis of cell-surface markers of peripheral blood Tcells. Peripheral blood mononuclear cells (PBMCs) were prepared (14), analyzed on a Coulter Epics XL flow cytometer (Coulter Cytometry, Hialeah, Florida, USA), and the absolute numbers of $\mathrm{CD}^{+}, \mathrm{CD}^{2} 5 \mathrm{RA}^{+}, \mathrm{CD} 2 \mathrm{~L}^{+} \mathrm{T}$ cells $\left(\mathrm{CD} 4^{+}\right.$naive-phenotype cells) and $\mathrm{CD}^{+}, \mathrm{CD}^{+} 5 \mathrm{RO}^{+} \mathrm{T}$ cells $\left(\mathrm{CD}^{+}\right.$memory-phenotype cells) were enumerated $(14,15)$.

In situ bybridization for HIV RNA expression in tissue sections. In situ hybridization for HIV RNA was performed by sectioning paraffin blocks and hybridizing the thymus section to a ${ }^{35}$ S-labeled RNA probe complementary to $>90 \%$ of the sequences in HIV-1 RNA (16).

Analysis of T-cell receptor repertoire and CDR3 size spectratyping. RNA was extracted from cryopreserved samples of PBMCs using the Ultraspec RNA Isolation System (Biotecx Laboratories Inc., Houston, Texas, USA). $\mathrm{CD}^{+} \mathrm{T}$ cells from week 47 PBMCs were isolated using magnetic beads coated with a CD4 MAB (DYNAL Inc., Lake Success, New York, USA). T-cell receptor (TCR) $\beta$-chain variable region (V $\beta$ ) mRNA expression was determined by reverse transcriptase-PCR (RT-PCR) (17). For CDR3 size spectratyping, electrophoresis of the RT-PCR products was performed with $6 \%$ polyacrylamide/urea gels. Gels were scanned on a PhosphorImager (Molecular Dynamics, Sunnyvale, California, USA), and CDR3 size analyzed using ImageQuant software (version 1.1; Molecular Dynamics). Data are shown for the 16 TCR V $\beta$ families that gave interpretable spectrotype patterns at each time point tested.

\section{Results}

Analysis of thymus tissue in patients who died with complications of HIV-1 infection. Thymus tissue was found in five of 
Table 1

Characteristics of HIV-infected patients studied at autopsy

\begin{tabular}{|c|c|c|c|c|c|c|c|c|c|c|}
\hline No. & $\begin{array}{l}\text { Age } \\
\text { at } \\
\text { death }\end{array}$ & Sex & $\begin{array}{l}\text { Duration } \\
\text { of HIV } \\
\text { infection } \\
\text { (years) }\end{array}$ & $\begin{array}{l}\text { CD4 } \\
\text { T cells } \\
\text { per mm } \mathrm{mm}^{3}\end{array}$ & $\begin{array}{c}\text { Complications } \\
\text { of HIV } \\
\text { infections, } \\
\text { cause of death }\end{array}$ & $\begin{array}{l}\text { HIV } \\
\text { treatment }^{\mathrm{A}}\end{array}$ & $\begin{array}{l}\text { Thymus } \\
\text { tissue } \\
\text { found at } \\
\text { autopsy }\end{array}$ & $\begin{array}{l}\text { Thymopoiesis } \\
\text { present }\end{array}$ & $\begin{array}{l}\text { Inflammatory } \\
\text { infiltration in } \\
\text { PVS around } \\
\text { thymic epithelium }\end{array}$ & $\begin{array}{l}\text { HIV-expressing } \\
\text { cells in thymus } \\
\text { by in situ } \\
\text { hybridization }\end{array}$ \\
\hline 1 & 42 & M & NA & 77 & $\begin{array}{l}\text { Progressive multifocal } \\
\text { leukoencephalopathy }\end{array}$ & None & Yes & No & Yes & No \\
\hline 2 & 29 & $\mathrm{~F}$ & 9 & 41 & $\begin{array}{l}\text { HIV nephropathy; } \\
\text { Candida esophagitis }\end{array}$ & ZDV, LMV & Yes & Yes & Yes & Yes \\
\hline 3 & 52 & M & 9 & 90 & $\begin{array}{l}\text { Varicella-zoster encephalitis; } \\
\text { Staphylococcus aureus pneumonia }\end{array}$ & ZDV & Yes & No & Yes & Yes \\
\hline 4 & 43 & M & 6 & NA & Gram-negative rod sepsis & NA & Yes & Yes & Yes & Yes \\
\hline 5 & 34 & M & 4 & 271 & $\begin{array}{c}\text { Staphylococcus aureus pneumonia; } \\
\text { EBV + B-cell lymphoma }\end{array}$ & $\begin{array}{l}\text { ZDV, LMV, } \\
\text { Indinavir }\end{array}$ & Yes & No & Yes & No \\
\hline 6 & 33 & M & 7 & 2 & $\begin{array}{l}\text { Disseminated mycobacterium avium } \\
\text { complex infection }\end{array}$ & $\begin{array}{l}\text { ZDV, LMV, } \\
\text { Indinavir }\end{array}$ & No & - B & - & - \\
\hline 7 & 32 & M & 3 & $108 \mathrm{~F}$ & $\begin{array}{l}\text { Progressive multifocal leukoencephalopathy; } \\
\text { Pneumocystis carinii pneumonia; } \\
\text { Histoplasma capsulatum pneumonia }\end{array}$ & ZDV & No & - & - & - \\
\hline
\end{tabular}

$\mathrm{CD} 4 \mathrm{~T}$ cells $/ \mathrm{mm}^{3}$ values shown are the last value obtained prior to death. ${ }^{A}$ Treatment listed is the last treatment prior to death. Viral load in patient no. $5 \mathrm{was}<120$ copies $/ \mathrm{ml}$ at the time of death. Data for the other patients were not available. ${ }^{B}$ Not applicable. $L M V$, lamivudine; NA, not available; PVS, perivascular space; ZDV, azidothymidine.

seven patients who died of complications of HIV-1 infection (Table 1). All thymuses had thymic inflammation present in the form of thymic perivascular space infiltrations with macrophages, B cells, and mature CD8 ${ }^{+}$, TIA- $1^{+}$cytotoxic effector T cells (Fig. $1, a-d$ ).

The presence of CD $1 \mathrm{a}^{+}, \mathrm{Ki}-67^{+}$cortical thymocytes in human thymus tissue signifies the presence of active thymopoiesis (1). We found areas of thymopoiesis in two of seven mediastinal tissues studied (patients nos. 2 and 4; Table 1), with foci of CD1a ${ }^{+}, \mathrm{Ki}-67^{+}$thymocytes in lobes of thymic epithelium (Fig. 1, $e-b$ ). The CD $4^{+} \mathrm{T}-$ cell level in patient no. 2 was below $50 / \mathrm{mm}^{3}$ for 51 months before death.

Chest computerized tomograms (CT) have been used to identify thymus tissue in vivo in adults (18-20) and in the analysis of thymopoiesis in adults with HIV-1 infection
(21). In patient no. 5, chest CT showed the typical triangular form of adult thymic tissue two days before death (Fig. 2). The histology of this patient's thymus at autopsy two days after the CT in Fig. 2 showed no active thymopoiesis; only perivascular space peripheral lymphoid infiltrate outside the epithelial thymus was present (Fig. 2b). Thus, a thymus shadow on chest $C T$ with radiodense lymphoid areas does not necessarily mean active thymopoiesis is present in the thymus. Rather, it can mean the presence of perivascular space peripheral lymphoid tissue in an otherwise nonfunctional organ.

In situ hybridization analysis for HIV-1 RNA demonstrated HIV-1-expressing cells in three of five thymuses tested in this group (Table 1 ). We found $\mathrm{HIV}-1^{+}$cells located among peripheral cells in the perivascular space as well as among thymocytes within the true epithelial thymus (Fig. 3).
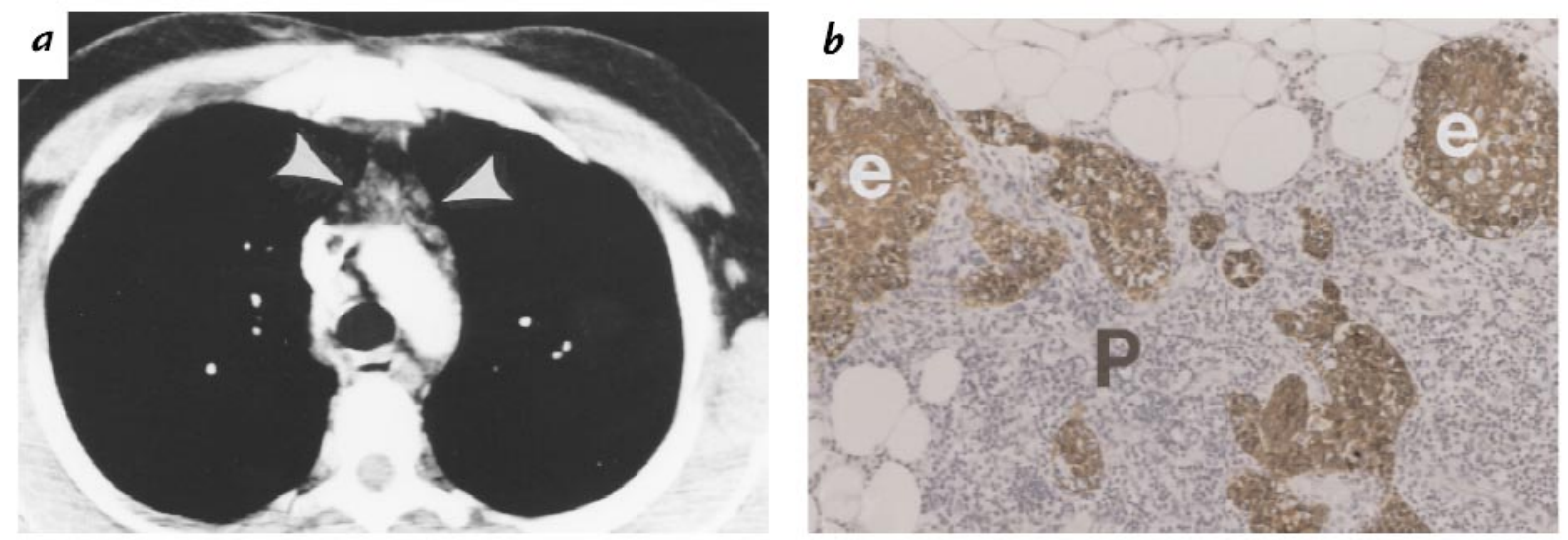

Figure 2

Lack of correlation of presence of a thymus shadow on computerized tomogram of the mediastinum with thymus tissue containing active thymopoiesis by histologic analysis. (a) Computerized tomogram of patient no. 5 in January 1998. Arrowheads point to a triangular thymus shadow typical for an adult. (b) Immunohistological analysis using antikeratin antibody of the thymus tissue taken at autopsy 2 days after the computerized tomogram in $a$, demonstrating empty keratin ${ }^{+}$thymic epithelium (e; brown areas) surrounded by an inflammatory-cell infiltrate (blue areas, arrows) in thymic perivascular space $(P)$. $\times 33$. No $\mathrm{CD} 1 \mathrm{a}^{+}$lymphocytes were present in the epithelial thymus; rather, the phenotype of mononuclear cells in the perivascular space demonstrated that the infiltrate contained monocytes, B cells, and mature CD8 ${ }^{+} \mathrm{T}$ cells, a subset of which was TIA-1+(not shown). 


\section{Figure 3}

HIV-1-expressing cells are present in the thymic perivascular space as well as in the true epithelial thymus. In situ hybridization for HIV-1 mRNA was performed in patient no. 2 in combination with immunohistological analysis for antikeratin antibody reactivity to identify the true thymic epithelial space (keratin $^{+}$) and the thymic perivascular space (keratin-). There are cells with HIV-1 RNA both in the islands of true thymus with brown-stained keratin ${ }^{+}$epithelium $(e)$ as well as in the intervening perivascular space $(P)$. In the developed radioautograph after in situ hybridization with radiolabeled HIV-1-specific probe, cells with HIV-1 RNA that bound probe have overlying collections of silver grains. Epipolarized light reflected from the grains imparts a yellow color to the cells.

HIV-1 infection in thymectomized patients. To address directly the question of the effect of removal of the thymus on the clinical course of HIV-1 infection, we identified patients who had been thymectomized for myasthenia gravis and who subsequently developed HIV infection. Although the thymus clearly functions in normal adults to produce new $\mathrm{T}$ cells, if the thymus were solely required for maintenance of the T-cell pool in HIV-1 infection, then the clinical course in these patients should be uniformly that of rapid progression to AIDS (22). If the thymus were required for HAART-induced rises in peripheral blood (PB) $\mathrm{CD}^{+} \mathrm{T}$-cell levels, then no rises of peripheral $\mathrm{CD} 4^{+}$ T-cell levels should occur in thymectomized subjects.

\section{Case reports}

Patient no. 8. In January 1987, this 25 -year-old woman began a sexual relationship with a HIV-1-infected man. In February 1987, she developed myasthenia gravis. Serum anti-HIV-1 antibodies were absent. In December 1987, she had a therapeutic thymectomy, and her weakness improved.

In March 1988, anti-HIV-1 antibodies were present. In August 1988, her CD4 ${ }^{+}$T-cell count was $1247 / \mathrm{mm}^{3}$. By November 1991, her CD4 $4^{+}$cell count was $99 / \mathrm{mm}^{3}$ (Fig. 4a). She experienced numerous AIDS-related conditions and died of Pneumocystis carinii pneumonia in March 1997. Chest CT in December 1996 demonstrated absence of thymus tissue.

Patient no. 9. In February 1988, this 22-year-old man engaged in sexual relations with an HIV-1-infected man.

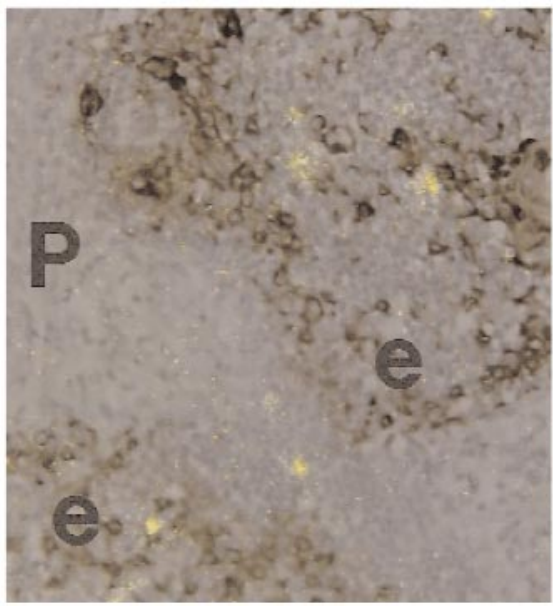

In May 1988, this patient developed myasthenia gravis. In June 1988, he underwent total thymectomy, and his weakness improved. In July 1988, HIV-1 antibodies were absent. In April 1989, he developed generalized lymphadenopathy. In September 1996, he sustained a 10pound weight loss and developed Pneumocystis carinii pneumonia. Serum anti-HIV-1 antibodies were present. His CD4+ T-cell count was 64/ $\mathrm{mm}^{3}$. In September 1996, his plasma HIV RNA was 69,112 copies/ml. On October 24,1996 , he began antiretroviral therapy with zidovudine, lamivudine, and indinavir. On December 12, 1996, his plasma HIV RNA level was < 95 copies/ml. In January 1997, a chest CT scan demonstrated no thymus tissue. In July 1998, he remained asymptomatic on antiretroviral therapy, and his CD4 ${ }^{+} \mathrm{T}$-cell count was $419 / \mathrm{mm}^{3}$.

Patient no. 10. In 1968, this 13-year-old male adolescent developed myasthenia gravis. At age 16, he had a total thymectomy for treatment of myasthenia gravis. From 1982 until 1992, he engaged in sexual relations with men. He had a positive test for serum HIV-1 antibodies in October 1992, and oral zidovudine was begun for asymptomatic HIV-1 infection. In April 1994, he developed Histoplasma capsulatum meningitis, which was treated with itraconazole. In March 1996, indinavir and

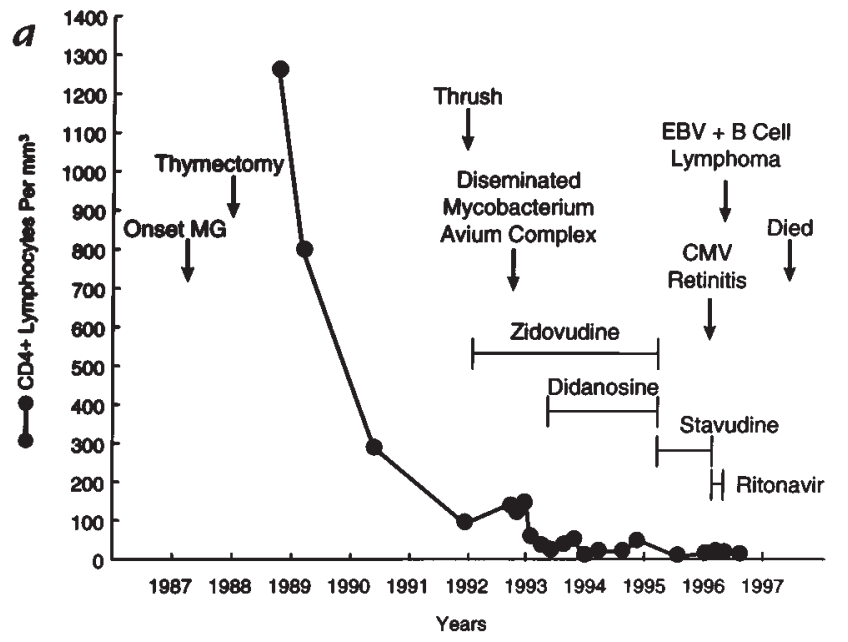

$b$

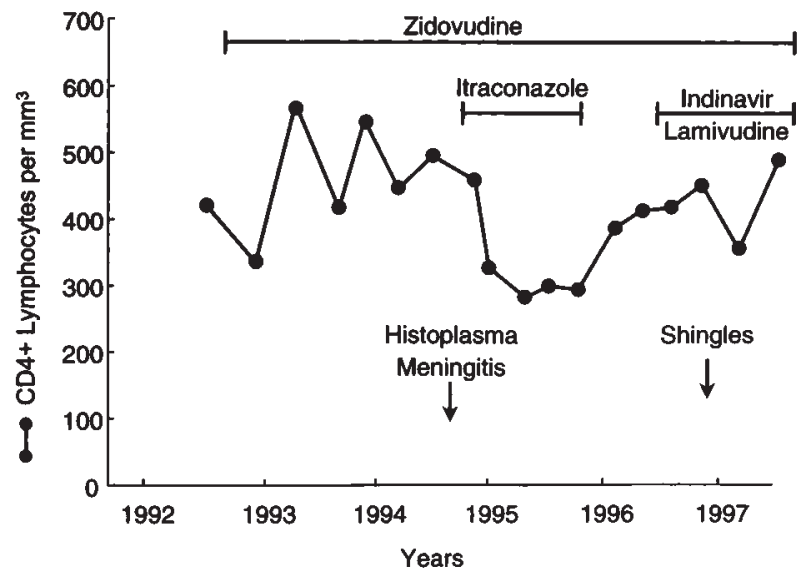

Figure 4

The clinical course of HIV-1 infection in patients nos. 8 and 10. (a) Clinical course of patient no. 8. (b) Clinical course of patient no. 10. 
lamivudine were added to zidovudine; he remained asymptomatic, and plasma HIV-1 RNA levels became undetectable. From 1992 until 1997, his CD4+ T-cell counts ranged from 285 to $572 / \mathrm{mm}^{3}$, with a CD4 ${ }^{+} \mathrm{T}$-cell level in July 1997 of 491/ $\mathrm{mm}^{3}$ (Fig. 4b). In October 1998, he remained asymptomatic.

Studies in HIV-1-infected thymectomized patients. We studied archived thymus tissue from patients nos. 8 and 9 by DNA PCR and found that the thymus of patient no. 8 was infected with HIV-1 in 1987, whereas patient no. 9's thymus was not infected at the time of thymectomy. Thus, we postulate that the presentation of myasthenia gravis in patient no. 8 in February 1987 represented primary HIV-1 infection, a previously described clinical syndrome $(23,24)$. The course of patient no. 8 was that of a rapid progressor to AIDS, with an average $\mathrm{CD} 4^{+} \mathrm{T}$-cell loss of 348 cells $/ \mathrm{mm}^{3} /$ year (25). She had an initial rise in $\mathrm{CD}^{+} \mathrm{T}$ cells from 99 to $140 / \mathrm{mm}^{3}$ on zidovudine in 1992 but had no further rises in $\mathrm{CD}^{+}{ }^{+} \mathrm{T}$ cells despite multiple changes in antiretroviral drugs (Fig. $4 a$ ). In contrast, the clinical course in patient no. 9 was that of a typical progressor to AIDS over a seven-year period, and patient no. 10 has remained asymptomatic seven years after testing positive for HIV, and 17 years after beginning to engage in sexual relations with men (Fig. 4b).

We next determined peripheral $\mathrm{CD}^{+} \mathrm{T}$-cell levels after HAART in patients nos. 9 and 10. Before HAART, approximately $80 \%$ of patient no. 9's $\mathrm{CD}^{+}{ }^{+} \mathrm{T}$ cells were $\mathrm{CD} 4 \mathrm{RA}^{+}, \mathrm{CD} 6 \mathrm{~L}^{+}$(naive T-cell phenotype) (ref. 15; Fig. $5 a)$. After HAART, both naive- and memory-phenotype populations of $\mathrm{CD}^{+}{ }^{+} \mathrm{T}$ cells rose as his total $\mathrm{CD} 4^{+} \mathrm{T}$-cell level rose from pretreatment levels of $106 / \mathrm{mm}^{3}$ to a peak of $306 / \mathrm{mm}^{3} 13$ weeks after initiation of HAART. These $\mathrm{CD}^{+} \mathrm{T}$-cell rises were similar to rises reported in nonthymectomized HAART-treated patients (9, 10). By approximately two years after initiation of HAART (week 95), his $\mathrm{CD}^{+} \mathrm{T}$-cell count had risen to $419 / \mathrm{mm}^{3}$. After week 24, the $\mathrm{CD}^{+}, \mathrm{CD}_{45 \mathrm{RA}^{+}}, \mathrm{CD}_{62} 2^{\mathrm{hi}}{ }^{+} \mathrm{T}$-cell number remained constant, whereas further rises in $\mathrm{CD}^{+} \mathrm{T}$-cell number were solely due to late rises in $\mathrm{CD}^{+}, \mathrm{CD}^{4} \mathrm{RO}^{+}$ T cells (Fig. 5a).

Patient no. 10 was only available for PB T-cell analysis in July 1997. Six months after addition of indinavir and lamivudine to zidovudine, his $\mathrm{CD}^{+} \mathrm{T}$-cell count rose from $388 / \mathrm{mm}^{3}$ to $453 / \mathrm{mm}^{3}$. In July 1997 , his CD4 ${ }^{+} \mathrm{T}$ cell count was $491 / \mathrm{mm}^{3}$ (Fig. $4 b$ ), with equal numbers of naive and memory $\mathrm{T}$ cells (Fig. $5 b$ ).

If the peripheral $\mathrm{T}$-cell reconstitution in thymectomized patient no. 9 was derived from proliferation of peripheral $\mathrm{T}$ cells and not from new cells from a thymus, then analysis of the TCR repertoire during HAART treatment would be expected to show few changes in TCR V $\beta$ region usage and to show no new diversity in $V \beta$ CDR3 length (10). Analysis of patient no. 9's PB TCR V $\beta$ repertoire for each V $\beta$ family from week 3, week 13 (not shown), and week 47 of HAART showed stable TCR V $\beta$ usage in most V $\beta$ families, using RT-PCR and CDR3 length analysis (Fig. 6, $a-c$ ). We found oligoclonal PB Tcell populations both before (week 3) and after (week 47) $\mathrm{CD}^{+}{ }^{+} \mathrm{T}$-cell rises in some $\mathrm{V} \beta$ families (e.g., $\mathrm{V} \beta 3, \mathrm{~V} \beta 6$, and $\mathrm{V} \beta 21$ in Fig. $6 a$ ), with the occasional appearance of rare new or increased size in T-cell populations (see, e.g., V $\mathrm{V3}$

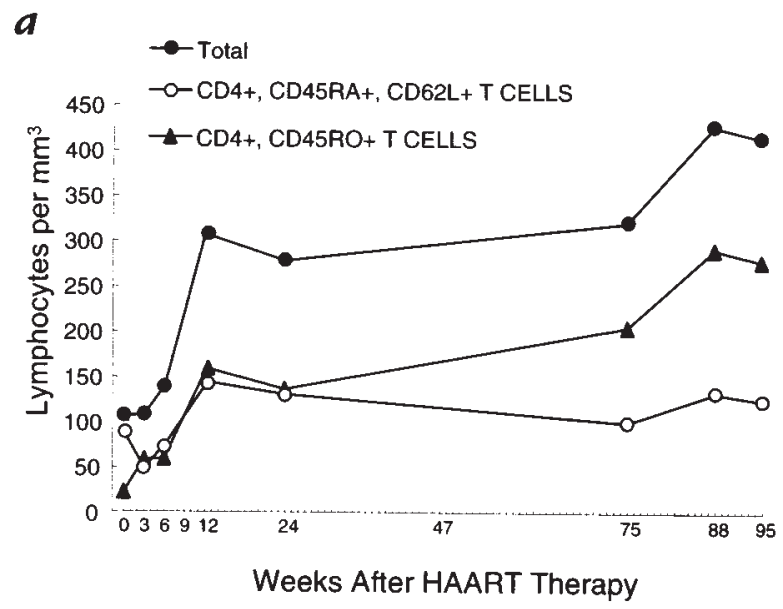

$\boldsymbol{b}$

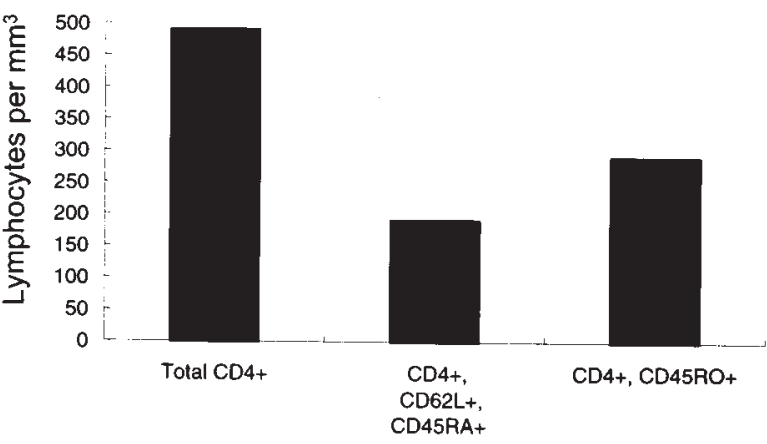

Figure 5

Response of HIV-1-infected thymectomized patients nos. 9 and 10 to HAART. (a) Patient no. 9 had rises in both naive-phenotype (CD4 ${ }^{+}, \mathrm{CD}_{4}$ RA ${ }^{+}$, $\left.\mathrm{CD} 2 \mathrm{~L}^{+}\right)$and memory-phenotype (CD4 $\left.{ }^{+}, \mathrm{CD} 45 \mathrm{RO}^{+}\right)$T cells after HAART. $(\boldsymbol{b})$ Naive and memory CD4 ${ }^{+} \mathrm{T}$-cell subsets in patient no. 10, 16 months after initiation of HAART. Both naive- and memory-phenotype PB T cells are present. Total lymphocyte counts and phenotypic analyses of PB T cells were performed on the same blood specimens for all patients except for the pretreatment and week 3 absolute lymphocyte counts on patient no. 9, which were obtained 24 and $48 \mathrm{~h}$, respectively, after the PB phenotype. HAART, highly active combination antiretroviral therapy; $P B$, peripheral blood.

and V 321$)$. At week 47, a similar pattern was seen in purified CD4 ${ }^{+} \mathrm{T}$ cells (Fig. $6 c$ ) as was seen in unfractionated PB T cells (Fig. 6b). Fig. $6 d$ shows a representative normal subject's CDR3 spectrotype analysis for comparison.

\section{Discussion}

To study the role of the human thymus in reconstitution of the T-cell arm of the immune system in HIV-1 infection, we analyzed mediastinal tissue from lymphopenic patients with HIV-1 infection and evaluated the clinical course of HIV-1 infection and response to HAART in thymectomized individuals.

Our study argues for minimal contributions of the thymus to maintenance or reconstitution of the peripheral pool of T cells in the adult HIV-1-infected patients in the two clinical settings evaluated in this study. First, mediastinal tissue analysis of AIDS patients from autopsy revealed that five of seven $(71 \%)$ patients had either no thymus or no areas of thymopoiesis, demonstrating that no contribution to the peripheral T-cell pool was being 
$a$
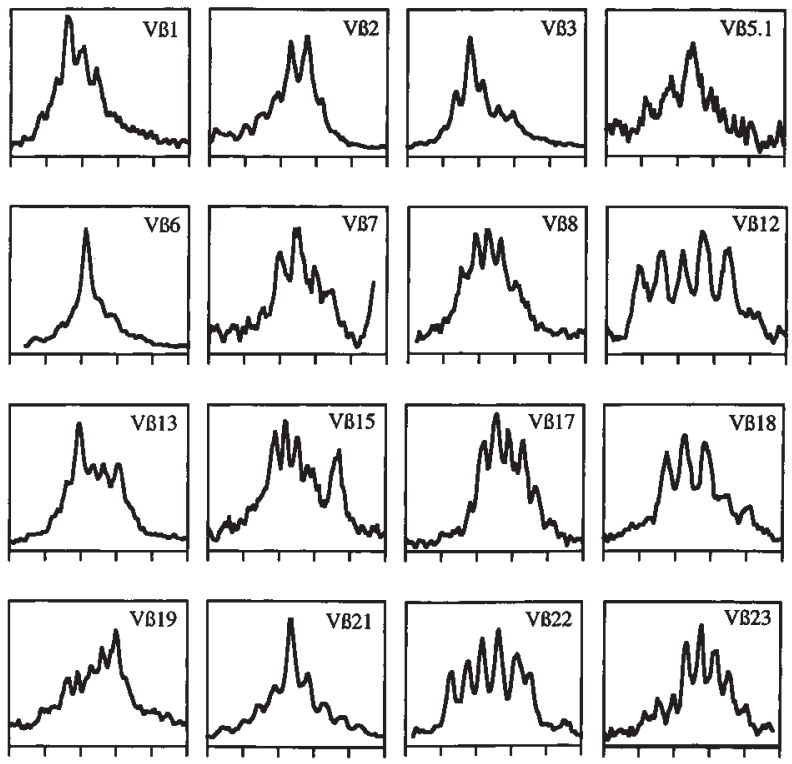

C
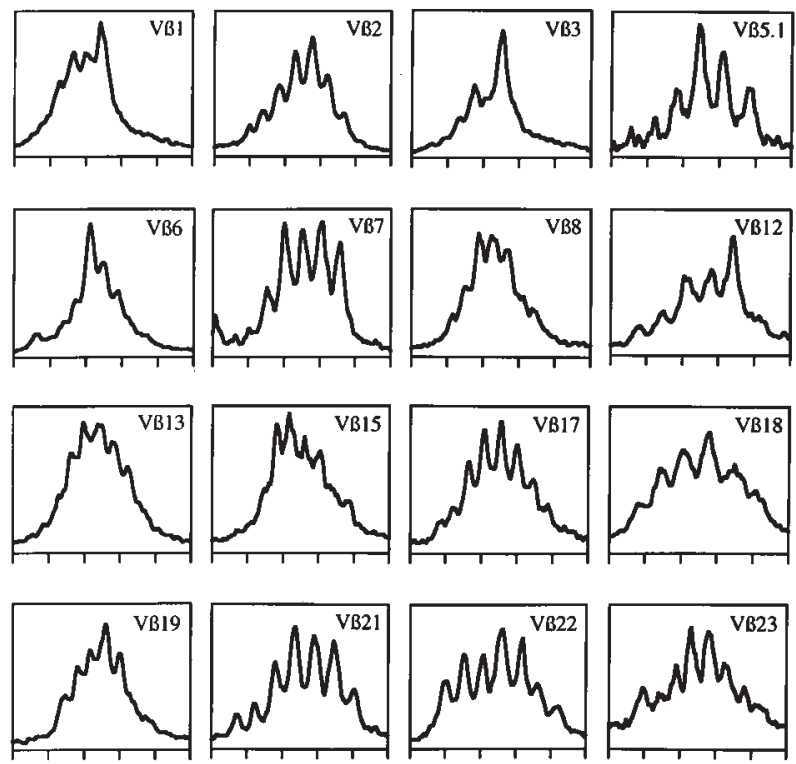

Figure 6

Analysis of TCR V $\beta$ repertoire diversity by spectratype analysis of TCR V $\beta$ CDR3 length. Shown is analysis for 16 TCR V $\beta$ families. ( $\boldsymbol{a}$ and $\boldsymbol{b}$ ) Analysis beginning before (week 3; a) and after (week 47; b) HAART-associated CD4 ${ }^{+}$T-cell rises in PB T cells. (c) Same analysis at week 47 in purified CD4 ${ }^{+} \mathrm{T}$ cells. Because of the recombination process of TCRs during T-cell development, TCR V $\beta$ CDR3 sizes vary by as many as eight amino acids between any two TCR chains. This method of TCR repertoire analysis combines RT-PCR technology with analysis of message size in acrylamide gels to determine the relative abundance of TCR transcripts bearing particular CDR3 sizes within a T-cell sample. Thus, more normal or polyclonal patterns of TCR usage are seen in $d$ in the study of a normal control. Less normal or oligoclonal patterns are seen in a for V $\beta 3$ and V $\beta 6$ T cells. Our analysis showed in patient no. 9 that TCR usage did not change in most V $\beta$ families over time. However, rare new or enhanced usage of TCR clones was documented by week 47 in several V $\beta$ families that were compatible with T-cell responses to antigenic challenge peripherally over time. $c$ shows that the TCR clone patterns seen in unfractionated PB T cells at week 47 were also similar to the patterns seen in purified $C D 4^{+} T$ cells assayed from the same time point. (d) For comparison, TCR repertoire analysis in a representative normal non-HIV-1-infected subject is shown; it demonstrates the normal spectrum of TCR CDR3 length analysis. $C D R 3$, complementary determining region-3; $R T$, reverse transcriptase; $T C R$, T-cell receptor; $V \beta$, $\beta$-chain variable region.

made by the thymus in those subjects at the time of death. Importantly, patient no. 2 had profound lymphopenia for 51 months before death, despite the presence of active thymopoiesis, demonstrating that the level of function in patient no. 2's thymus was unable to reconstitute the peripheral T-cell pool in this patient. However, because patients nos. 1-7 were studied at the time of death in order to evaluate thymus tissue, the observation of no (or ineffective) thymic function in this patient group was not unexpected. A critical question 
was whether the absence of a functional thymus negatively affects clinical outcome of HIV infection.

This question was studied in three patients who were thymectomized either before or during primary HIV infection. We found that thymectomy did not preclude longterm survival or prevent the presence or rise of naive-phenotype peripheral T cells after HAART (patients nos. 9 and 10). The observations of rises in naive-phenotype $\mathrm{CD}^{+} \mathrm{T}$ cells that were CD45RA ${ }^{+}$and $\mathrm{CD}^{2} 2 \mathrm{~L}^{+}$in patients thymectomized nine years (patient no. 9) and 26 years (patient no. 10) before HAART demonstrated that $\mathrm{CD}^{+} \mathrm{T}$ cells with this phenotype are not exclusively of recent thymic origin and demonstrated this phenomenon to be thymus-independent (26). In this regard, Walker et al. (27) have recently demonstrated, using genetically marked and infused CD4 ${ }^{+}$ $\mathrm{T}$ cells, that a major component of regenerating $\mathrm{T}$ cells in HIV-infected adults is derived from peripheral expansion of mature $T$ cells. In this study, the reversion of memory-phenotype $\left(\mathrm{CD} 45 \mathrm{RO}^{+}\right) \mathrm{T}$ cells to naive-phenotype (CD45RA $\left.{ }^{+}\right)$ $T$ cells in the setting of HIV infection was documented to occur (27). Interestingly, in patient no. 9, after the initial rise in $\mathrm{CD}^{+}, \mathrm{CD}^{2} 4 \mathrm{RA}^{+}, \mathrm{CD}^{2} 2^{\text {hi+ }} \mathrm{T}$ cells at weeks $13-24$ after HAART, subsequent late $\mathrm{CD} 4^{+} \mathrm{T}$-cell increases were due to increased numbers of $\mathrm{CD}^{+}, \mathrm{CD}^{4} \mathrm{RO}^{+} \mathrm{T}$ cells (Fig. $5 \mathrm{a}$ ).

The T-cell repertoire can be oligoclonal both before and after HAART in HIV-1 $1^{+}$infection $(10,17,25,28)$. If the thymus or another source were adding to the peripheral pool in adults in this setting, the T-cell V $\beta$ CDR3 repertoire could change toward more diverse TCR usage. We saw only a few changes in the TCR repertoire of T cells of patient no. 9 either before or after HAART-induced increases in peripheral CD4 ${ }^{+} \mathrm{T}$ cells (Fig. $6 b$ ). The appearance of new TCR clones at week 47 was compatible with peripheral T-cell responses to new antigenic challenges. Connors et al. (10) demonstrated similar findings in nonthymectomized HIV$1^{+}$patients on HAART, with few changes in TCR repertoires over time. Gorochov et al. (28) recently have used these same techniques to observe normalization of the $\mathrm{CD} 4^{+} \mathrm{T}$-cell repertoire in select patients after long-term ( $>6$ months) treatment with HAART. Zhang et al. (29) have shown HAART-induced repair of peripheral lymph node architecture and restoration of lymph node $\mathrm{CD}^{+}{ }^{+} \mathrm{T}$-cell populations over time. It is reasonable to expect that if peripheral lymph node microenvironments are capable of healing on HAART, then the central thymic microenvironment on HAART might be expected to heal as well. McCune et al. (21) have recently demonstrated that approximately $50 \%$ of the $\mathrm{HIV}-1^{+}$patients studied had abundant thymic tissue detected by CT scan and that the presence of thymic tissue correlated with the number of circulating $\mathrm{CD}^{+}$naive-phenotype cells. Thus, those patients who have functional thymic tissue present before HAART might be expected to regain thymic function after HAART (21).

Recently, Douek et al. (30) have studied thymus function in HIV infection using the analysis of the products of TCR $\alpha$-chain recombination, termed episomal T-cell receptor excised circles (TRECs). TRECs are markers of naive T cells that either have just left the thymus or have not divided since thymic emigration (30). These investigators demonstrated measurable thymic function in normal adults $<50$ years old by observing HAART-associated increases in $\mathrm{TREC}^{+}, \mathrm{CD}^{+}$, $\mathrm{CD}^{2} 5 \mathrm{RA}^{+} \mathrm{T}$ cells in HIV-infected adults (30). Taken togeth- er with our studies in the present report, these data argue strongly both for contributions of the thymus and for expansion of the peripheral T-cell pool in reconstitution of $\mathrm{T}$ cells in nonthymectomized HIV-infected patients on HAART. We recently used TREC analysis to study patient no. 9 at weeks 24 and 95 and found that TREC levels were extremely low at both time points (at levels Douek et al. [30] described previously for thymectomized subjects), confirming that, indeed, the expansion of $\mathrm{CD}^{+}{ }^{+} \mathrm{CD} 45 \mathrm{RA}^{+}, \mathrm{CD}^{2} 2^{\mathrm{hi}}{ }^{+}$ $\mathrm{T}$ cells at week 24 and the expansion of $\mathrm{CD} 4^{+} \mathrm{T}$ cells at week 95 were derived solely from peripheral T cells (Haynes, B.F., et al., unpublished observations).

Previous studies (31-38) have demonstrated the morphology of the thymus in various stages of HIV-1 infection and have described the presence of thymitis with Bcell germinal centers in the thymic medulla in early HIV-1 infection, as well as calcification and thymic atrophy with epithelial collapse in the late stages of HIV infection. However, few investigators have appreciated the findings of Steinmann et al. (39) and Bofill et al. (40) that the true thymus neither fills up with adipose tissue during aging nor fills up with inflammatory cells during myasthenia gravis. Rather, in aging and myasthenia gravis, cellular infiltrates and adipose tissue fill the perivascular space around true thymus lobules, with eventual collapse of the epithelial component of the thymus $(39,40)$. Our study has shown that, just as in myasthenia gravis, most of the lymphocytic infiltrate in HIV1 -infected thymuses is located within the perivascular space surrounding the thymic epithelium and contains peripheral $\mathrm{CD}^{+}$, TIA- $1^{+}$, CTL effector cells. Thus, although the HIV-infected thymus can appear lymphoid using hematoxylin and eosin stains, and on CT scan can demonstrate lymphoid areas (patient no. 5; Fig. $2 a$ ), the thymic lymphoid component in the late stages of AIDS can be made up either partially or totally of peripheral immune cells within the thymic perivascular space.

Thus, the human thymus can be thought of as a chimeric organ composed of a peripheral lymphoid component (the perivascular space) and a central lymphoid component (the true epithelial thymus) (41). Interestingly, we found HIV-1-expressing cells in both the perivascular space (40) and within the true epithelial thymus (Fig. 3). Whether the involution and collapse of the true thymic epithelial component occurs primarily because of direct effects of HIV-1 infection on thymocytes or occurs secondarily because of adjacent inflammatorycell infiltration of the perivascular space is not known.

It is important to emphasize that our studies only pertain to HIV-1 infection in older adults, and not to HIV-1 infection in children or to adults $<20$ years old. In HIV-1 ${ }^{+}$ infants, those with T-cell lymphopenia within the first six months of life were at greater risk for rapid progression to AIDS compared with nonlymphopenic HIV- $1^{+}$infants (42). Thus, in children, and perhaps in young adults, disruption of the thymic microenvironment by HIV-1 may result in reduced post-thymic T-cell reservoirs (42).

In summary, our study demonstrates that thymopoiesis can be present in HIV-1-infected thymuses and yet not correct peripheral lymphopenia and that thymectomy before HIV-1 infection does not prevent HAART-induced peripheral CD4 ${ }^{+} \mathrm{T}$-cell rises or preclude 
long-term survival with HIV-1 infection. Critical questions remain regarding the nature of control mechanisms of limited peripheral T-cell expansion after HAART and in understanding how to drive the postnatal thymus and peripheral lymphoid tissues to regenerate HIV-damaged immune systems.

\section{Acknowledgments}

The authors acknowledge the expert technical assistance of Jie Li; M. Louise Markert for identification of patients and discussions; John S. Sundy, Jonathan Baron, and Gregory D. Sempowski for sample processing; and Janet Ottinger for performance of the flow cytometry assays. The authors also acknowledge the expert secretarial assistance of Kim R. McClammy and the dedication of our patients studied in these protocols. Supported by National Institutes of Health grants CA-28936, AI-28246, AI-28662, AI29852, and AI-38587.

1. Haynes, B.F., Denning, S.M., Le, P.T., Singer, K.H. 1990. Human intrathymic T cell differentiation. Sem. Immunol. 2:67-77.

2. Mackall, C.L., et al. 1993. T-cell regeneration after bone marrow transplantation: differential CD45 isoform expression on thymus-derived versus thymic-independent progeny. Blood. 82:2585-2594

3. Mackall, C.L., et al. 1995. Age, thymopoiesis, and CD4+ T lymphocyte regeneration after intensive chemotherapy. N. Engl. J. Med. 332:143-149.

4. Mackall, C.L., Hakim, F.T., and Gress, R.E. 1997. T-cell regeneration: all repertoires are not created equal. Immunol. Today. 18:245-251.

5. Wei, X., et al. 1995. Viral dynamics in human immunodeficiency virus type I infection. Nature. 373:117-122.

6. Ho, D.D., et al. 1995. Rapid turnover of plasma virions and CD4 lymphocytes in HIV-1 infection. Nature. 373:123-126.

7. Rosenberg, Y.J., Anderson, A.O., and Pabst, R. 1998. HIV-induced decline in blood CD4/CD8 ratios: viral killing or altered lymphocyte trafficking? Immunol. Today. 19:10-17.

8. Wolthers, K.C., Shuitemaker, H., and Miedema, F. 1998. Rapid CD4+ T-cel turnover in HIV-1 infection: a paradigm revisited. Immunol. Today. 19:44-48.

9. Autran, B., et al. 1997. Positive effects of combined antiretroviral therapy on CD4+ cell homeostasis and function in advanced HIV disease. Science. 277:112-116.

10. Connors, M., et al. 1997. HIV infection induces changes in CD4+ T-cell phenotype and depletions within the CD4+ T-cell repertoire that are not immediately restored by antiviral or immune-based therapies. Nat. Med. 3:533-540.

11. Hammer, S., et al. 1997. A controlled trial of two nucleoside analogues plus indinavir in persons with human immunodeficiency virus infection and CD4 cell counts of 200 per cubic millimeter or less. N. Engl. J. Med. 337:725-733.

12. Key, G., et al. 1993. New Ki-67 equivalent murine monoclonal antibodies (MIB 1-3) generated against bacterially expressed parts of the Ki-67 cDNA containing three 62 base pair repetitive elements encoding for the Ki-67 epitope. Lab. Invest. 68:629-636.

13. Tenner-Racz, K., et al. 1993. Cytotoxic effector cell granules recognized by monoclonal antibody TIA-1 are present in CD8+ lymphocytes in lymph nodes of human immunodeficiency virus-1 infected patients. Am. J. Pathol. 142:1750-1758.

14. Bartlett, J.A., et al. 1998. Safety and immunogenicity of an HLA-based HIV envelope polyvalent synthetic peptide immunogen in HIV-infected HLA B7 positive subjects. AIDS. 12:1291-1300.

15. Picker, L.J., et al. 1993. Control of lymphocyte recirculation in man. I. Differential regulation of the peripheral lymph node homing receptor $\mathrm{L}$ selectin on T cells during the virgin to memory cell transition. J. Immunol. 150:1105-1121.

16. Cavert, W., et al. 1997. Kinetics of response in lymphoid tissues to antiretroviral therapy of HIV-1 infection. Science. 276:960-964.
17. Pantaleo, G., et al. 1994. Major expansion of CD8+ T lymphocytes with a predominant $V \beta$ usage during the primary immune response to HIV. Nature. 370:463-467.

18. Dixon, A.K., et al. 1981. Computed tomography and histological correlation of the thymic remnant. Clin. Radiol. 32:255-257.

19. Moore, A.V., et al. 1983. Age-related changes in the thymus gland: CTpathologic correlation. Am. J. Radiol. 141:241-246.

20. Kissin, C.M., Husband, J.E., Nicholas, D., Eversman, W. 1987. Benign thymic enlargement in adults after chemotherapy: CT demonstration. Thorac. Radiol. 163:67-70.

21. McCune, J.M., et al. 1998. High prevalence of thymic tissue in adults with human immunodeficiency virus-1 infection. J. Clin. Invest. 101:2301-2308.

22. Haynes, B.F., et al. 1996. Toward an understanding of the correlates of protective immunity of HIV infection. Science. 271:324-328.

23. Wessel, H.B., and Zitelli, B.J. 1987. Myasthenia gravis associated with human T-cell lymphotropic virus type III infection. Ped. Neurol. 3:238-239.

24. Authier, F.-J., DeGrissac, N., Degos, J.-D., and Gherardi, R.K. 1995. Transient myasthenia gravis during HIV infection. Muscle Nerve. 18:914-916.

25. Pantaleo, G., et al. 1997. The qualitative nature of the primary immune response to HIV infection is a prognosticator of disease progression independent of the initial level of plasma viremia. Proc. Natl. Acad. Sci. USA. 94:254-258.

26. Pakker, N.G., et al. 1998. Biphasic kinetics of peripheral blood T cells after triple combination therapy in HIV-1-infection: a composite of redistribution and proliferation. Nat. Med. 4:208-214.

27. Walker, R., et al. 1998. Peripheral expansion of pre-existing mature T cells is an important means of CD4+ T-cell regeneration HIV-infected adults. Nat. Med. 4:852-856

28. Gorochov, G., et al. 1998. Perturbation of CD4+ and CD8+ T-cell repertoires during progression to AIDS and regulation of the CD4+ repertoire during antiviral therapy. Nat. Med. 4:215-221.

29. Zhang, Z.Q., et al. 1998. Kinetics of CD4+ T cell repopulation of lymphoid tissues after treatment of HIV-1 infection. Proc. Natl. Acad. Sci. USA. 5:1154-1159.

30. Douek, D.C., et al. 1998. Changes in thymic output with age and during the treatment of HIV infection. Nature. 396:690-695

31. Seemayer, T.A., et al. 1984. Precocious thymic involution manifest by epithelial injury in the acquired immune deficiency syndrome. Hum. Pathol. 15:469-474.

32. Joshi, V.V., et al. 1984. Pathology of suspected acquired immune deficiency syndrome in children: a study of eight cases. Pediatr. Pathol. 2:71-87.

33. Joshi, V.V., and Oleske, J.M. 1985. Pathologic appraisal of the thymus gland in acquired immunodeficiency syndrome in children. Arch. Pathol. Lab. Med. 109:142-146.

34. Grody, W.W., Fligiel, S., and Naeim, F. 1985. Thymus involution in the acquired immunodeficiency syndrome. Am. J. Clin. Pathol. 84:85-95.

35. Savino, W., et al. 1986. Thymic epithelium in AIDS: an immunohistologic study. Am. J. Pathol. 122:302-307.

36. Linder, J. 1987. The thymus gland in secondary immunodeficiency. Arch. Pathol. Lab. Med. 111:1118-1122.

37. Schuurman, H.J., et al. 1989. The thymus in acquired immune deficiency syndrome: comparison with other types of immunodeficiency diseases, and presence of components of human immunodeficiency virus type 1. Am. J. Pathol. 134:1329-1338.

38. Burke, A.P., et al. 1995. Localization of human immunodeficiency virus 1 RNA in thymic tissues from asymptomatic drug addicts. Arch. Pathol. Lab. Med. 119:36-41.

39. Steinmann, G.G. 1986. Changes in the human thymus during aging. Curr. Top. Pathol. 75:43-88.

40. Bofill, M., et al. 1985. Microenvironments in the normal thymus and the thymus in myasthenia gravis. Am. J. Pathol. 119:462-473.

41. Haynes, B.F., and Hale, L.P. 1998. The human thymus: a chimeric organ comprised of central and peripheral lymphoid components. Immunol. Res. 18:61-78

42. Kourtis, A.P., et al. 1996. Early progression of disease in HIV-infected infants with thymus dysfunction. N. Engl. J. Med. 335:1431-1436. 